\title{
Zinc and cadmium accumulation in different parts of wild plants of the Asteraceae family and Triticum aestivum
}

\author{
Victor Chaplygin, Saglara Mandzhieva*, Yuri Litvinov, Natalia Kravtsova, Aleksey \\ Sherstnev, Natalia Chernikova, and Irina Deryabkina \\ Southern federal university, 344090 Rostov-on-Don, Russia
}

\begin{abstract}
The regularities of the accumulation and distribution of metals $(\mathrm{Zn}$ and $\mathrm{Cd})$ in various parts of wild herbaceous plants and the agricultural crop of the impact zone in Rostov region (Russia) was considered. A large accumulation of elements in wild herbaceous plants of the Asteraceae family was noted compared with Triticum aestivum. The pollution of Triticum aestivum by $\mathrm{Cd}$ was observed. Wild herbaceous plants of the Asteraceae family were contaminated mostly with $\mathrm{Zn}$. It was found that Artemisia austriaca and Ambrosia artemisiifolia accumulated $\mathrm{Zn}$ and $\mathrm{Cd}$ in the aboveground part. Achillea nobilis accumulated $\mathrm{Cd}$ mainly in the root system. Closer location monitoring plots to the source of anthropogenic load and the location of the northwest winds prevailing in the region were main influencing factors leading to higher pollution.
\end{abstract}

\section{Introduction}

Excessive accumulation of heavy metals (HM) in crops, which is used for feed and food purposes poses a serious threat to human and animal health $[1,2]$. The investigation of the HM accumulation by plants is one of the most important and, at the same time, the most difficult aspects of environmental monitoring. Many HMs are essential microelements for all plants. For example, $\mathrm{Cu}$ is a part of a number of proteins and enzymes, mainly redox, $\mathrm{Zn}$ is necessary for photosynthesis and participates in nitrogen metabolism, and $\mathrm{Cd}$ activates a number of zinc-dependent enzymes: tryptophan oxygenase, carboxypeptidase. However, their high concentrations are dangerous for the vital functions of plants [3, 4]. Different plant species are characterized by selective absorption of trace elements from the soil and localization of them in various organs. It must be noted that each plant has a specific type of resistance mechanism to technogenic pollution due to the action of physiological barriers. The selectivity of HM accumulation by plants depends on the level of technogenic load and the type of plant species [5]. Wild plant species are much better adapted to anthropogenic stress than crops. To understand how adaptation mechanisms are formed it is necessary to study and compare the sustainability of wild and cultivated plants to HM

\footnotetext{
*Corresponding author: msaglara@mail.ru
} 
accumulation in soil. In this regard, territories subject to long-term industrial pollution are important objects for studying the distribution of trace elements in plant communities [6].

Accumulation of HM in plants is especially relevant in agricultural regions of Rostov region (Russia) where industrial enterprises are often closely adjacent to agricultural land [7]. Under such conditions the studying of the HM translocation into plants is of the greatest importance, making it possible to predict the effects of technogenic pollution on the environment.

The most common HM in industrial emissions related to the first hazard class are $\mathrm{Zn}$ and $\mathrm{Cd}$. These metals are the most toxic elements that have multiple toxic effects on plants [8-10]. So, Zn excess in the soil leads to a significant decrease in the ratio of root biomass to plant shoot biomass, which is caused by inhibition of root growth. The toxic concentration of $\mathrm{Cd}$ in plants leads to impaired enzyme activity and transpiration, inhibition of photosynthesis, and recovery of $\mathrm{NO}_{2}$ to NO. With an excess of metal in plants, growth retardation occurs, the root system is damaged and leaf chlorosis develops. In addition, these elements demonstrate similar geochemical behavior and have additive properties, replacing each other in the physiological processes in plants $[5,11]$.

The aim of this work was to analyze the accumulation of zinc $(\mathrm{Zn})$ and cadmium $(\mathrm{Cd})$ by various organs of soft wheat (Triticum aestivum) and wild plants of the Asteraceae family which grown in the Rostov region.

\section{Objectives and methods}

Monitoring sites No. 1 - 4 were located at a distance of 1.6 to $2.2 \mathrm{~km}$ in various directions from the Novocherkasskaya State District Power Station (NSDPS), the largest fuel and energy complex in the Rostov Region (Russia) (Fig. 1). The most common species of wild herbs in the studied area represents by Asteráceae family: ragweed (Ambrosia artemisiifolia L.), Austrian wormwood (Artemisia austriaca Pall. Ex. Wild) and noble yarrow (Achillea nobilis L.). Despite its proximity to NSDPS there are fields sown with oilseed and cereal crops and grazing. Additional sites no. 1a, 2a, 3a, 4a were laid to study Triticum aestivum. These sites located on the farmland adjacent to monitoring sites of No. 1, 2, 3, and 4 which further situated on virgin lands or fallow lands. The soil of the monitoring plots in fallow and arable areas is represented by Haplic Chernozem.

Plants species were sampled annually in the first half of July 2015-2019 in the phase of full ripeness of Triticum aestivum, as well as mass flowering of numerous representatives of the steppe forbs. The sampling period was chosen due to the fact that the maximum entry of elements into the plants takes place at this stage [12]. The raw weight of each plant species was at least $2 \mathrm{~kg}$. The roots were sampled together with soil to avoid loss of the root system mass. The plants were dried to an air-dry state. Plants aboveground part (stems and leafs) and roots were separated from each other and ground up. Prior to grinding, the roots were cleared of soil particles. In the samples of plants $\mathrm{Zn}$ and $\mathrm{Cd}$, which are present in the emissions of NSDPS, were determined [13]. The mineralization of plant samples was performed by the dry ashing method $[14,15]$. For analysis, a 1-gram oven-dried at $65^{\circ} \mathrm{C}$ plant sample was used. Samples were ashed for 6 hours in a muffle furnace at a temperature of $500{ }^{\circ} \mathrm{C}$. Ash was dissolved in $5 \mathrm{ml}$ of a $20 \% \mathrm{HCl}$ solution and after 2-3 minutes filtered through a paper filter. $\mathrm{Zn}$ and $\mathrm{Cd}$ concentration was determined on an atomic absorption spectrophotometer (Quant 2-AT, Kortek, Russia). All studies were performed in triplicate.

The HM pollution in plants was assessed by comparing the concentration of elements in plants with the maximum permissible level (MPL) for forage grasses [16]. 


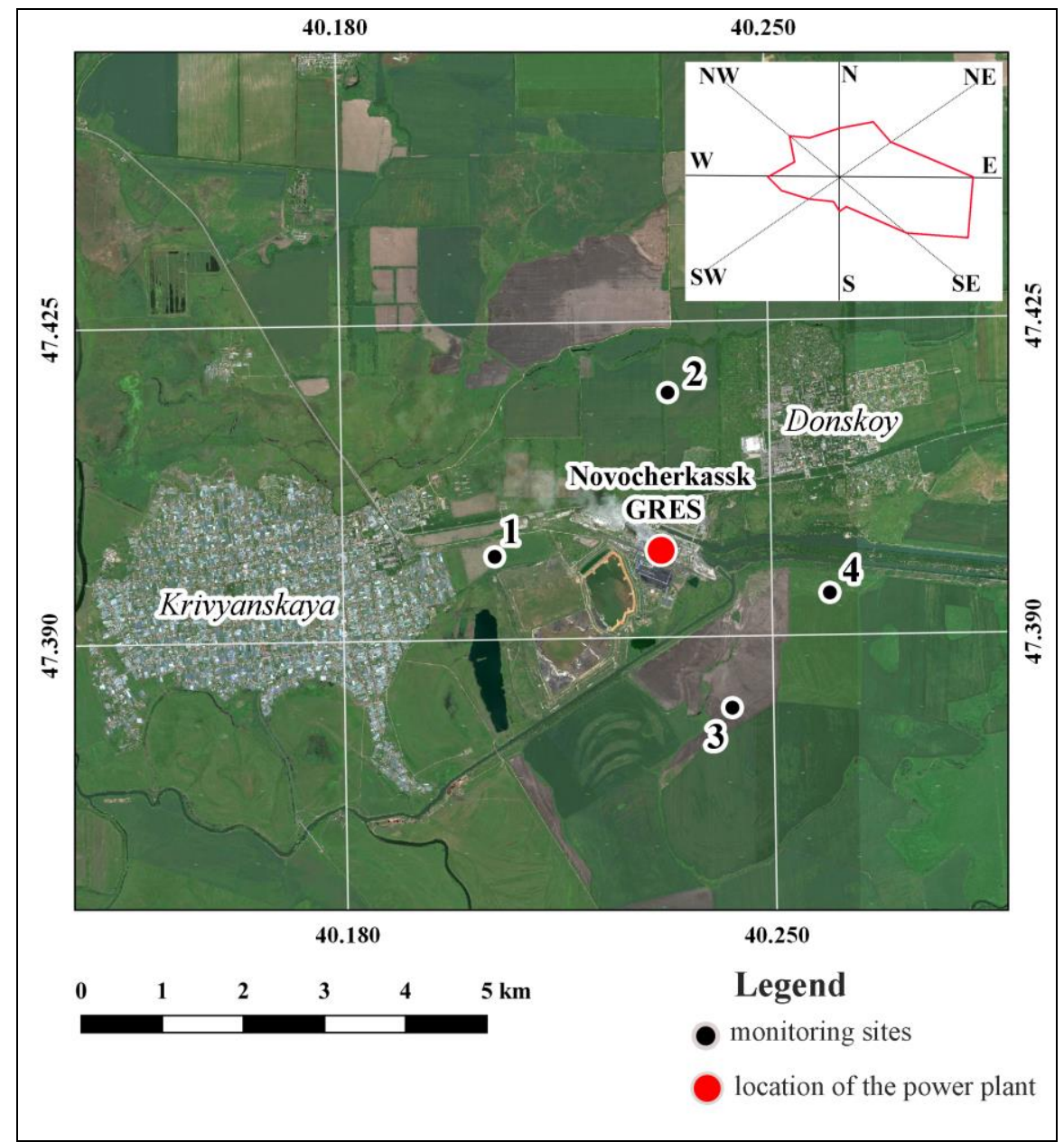

Fig. 1. Monitoring sites location.

\section{Results and discussion}

The monitoring of territories around NSDPS showed steady $\mathrm{Cd}$ pollution of plants. The excess of the MPL in Triticum aestivum straw for $\mathrm{Cd}$ was found to be at sites No. 1a and No. 2a (2.2-5.3 times, respectively) (Table 1). The $\mathrm{Cd}$ is known to be relatively easily transmitted from the roots into the aboveground parts, leading to relatively large amounts to penetrate the assimilate in storage organs $[9,17]$. The $\mathrm{Zn}$ and $\mathrm{Cd}$ mainly accumulated in the root system of Triticum aestivum.

Artemisia austriaca is characterized by the accumulation of $\mathrm{Zn}$ and $\mathrm{Cd}$ in the aboveground part (Table 1). For this type of plant, an excess of MPL by Zn was found to be 1.8 times at site No. 4. Moreover, an excess of MPL by Cd at sites No. 1 and No. 4 were 2.4 and 1.1 times, respectively.

For Achillea nobilis, Cd pollution was observed at monitoring sites No. 1 and No. 2 , accounting for1.5-3.3 MPL, respectively. It was also found that the MPL for Zn exceeded by 1.9 times at site No. 4. Achillea nobilis accumulated Cd mainly in the root system (Table $1)$.

Plants of Ambrosia artemisiifolia were observed to be contaminated with $\mathrm{Zn}$ at sites No. 1 and No. 4 with a factor of 2.4 and 1.4 MPL, respectively. For this plant, Cd at sites No. 1 
was found to be 2.4 MPL. This species was characterized by a predominant accumulation of $\mathrm{Zn}$ and $\mathrm{Cd}$ in the aboveground part (Table 1).

By the accumulation of metals in the aboveground part, plants can be represented in the following orders:

Zn: Ambrosia artemisiifolia $>$ Achillea nobilis $>$ Artemisia austriaca $>$ Triticum aestivum

Cd: Triticum aestivum $>$ Achillea nobilis $>$ Artemisia austriaca > Ambrosia artemisiifolia

For the content of HM in plant roots, the sequences were found to be as follows:

$\mathrm{Zn}$ : Achillea nobilis $>$ Ambrosia artemisiifolia $>$ Triticum aestivum $\geq$ Artemisia austriaca

Cd: Triticum aestivum $>$ Achillea nobilis $>$ Artemisia austriaca $>$ Ambrosia artemisiifolia.

Table 1. The content of heavy metals in the aboveground part and roots of plants at monitoring sites, $\mathrm{mg} / \mathrm{kg}$.

\begin{tabular}{|c|c|c|c|c|c|}
\hline \multirow[b]{2}{*}{ Sites No. } & \multirow[b]{2}{*}{ Plant } & \multicolumn{2}{|c|}{$\mathbf{Z n}$} & \multicolumn{2}{|c|}{ Cd } \\
\hline & & $\begin{array}{c}\text { The } \\
\text { aboveground } \\
\text { part }\end{array}$ & Roots & $\begin{array}{c}\text { The } \\
\text { aboveground } \\
\text { part }\end{array}$ & Roots \\
\hline 1a $(1.6 \mathrm{NW})$ & $\begin{array}{l}\text { Triticum } \\
\text { aestivum }\end{array}$ & $24 \pm 2$ & $46 \pm 4$ & $1.60 \pm 0.12$ & $1.80 \pm 0.05$ \\
\hline \multirow{3}{*}{$1(1.6 \mathrm{NW})$} & $\begin{array}{l}\text { Artemisia } \\
\text { austriaca }\end{array}$ & $51 \pm 5$ & $118 \pm 9$ & $0.73 \pm 0.07$ & $2.00 \pm 0.06$ \\
\hline & Achillea nobilis & $19 \pm 3$ & $109 \pm 10$ & $1.00 \pm 0.08$ & $2.12 \pm 0.07$ \\
\hline & $\begin{array}{c}\text { Ambrosia } \\
\text { artemisiifolia }\end{array}$ & $122 \pm 13$ & $98 \pm 9$ & $0.73 \pm 0.08$ & $1.26 \pm 0.12$ \\
\hline $2 \mathrm{a}(1.5 \mathrm{~N})$ & $\begin{array}{l}\text { Triticum } \\
\text { aestivum }\end{array}$ & $14 \pm 1$ & $30 \pm 1$ & $0.53 \pm 0.04$ & $0.70 \pm 0.09$ \\
\hline \multirow{3}{*}{$2(1.5 \mathrm{~N})$} & $\begin{array}{l}\text { Artemisia } \\
\text { austriaca }\end{array}$ & $28 \pm 3$ & $20 \pm 1$ & $0.18 \pm 0.01$ & $0.13 \pm 0.02$ \\
\hline & Achillea nobilis & $48 \pm 6$ & $42 \pm 3$ & $0.44 \pm 0.04$ & $0.13 \pm 0.02$ \\
\hline & $\begin{array}{c}\text { Ambrosia } \\
\text { artemisiifolia } \\
\end{array}$ & $40 \pm 4$ & $35 \pm 3$ & $0.24 \pm 0.02$ & $0.08 \pm 0.01$ \\
\hline 3a (2.2 SE) & $\begin{array}{l}\text { Triticum } \\
\text { aestivum }\end{array}$ & $8 \pm 1$ & $7 \pm 1$ & $0.31 \pm 0.02$ & $0.44 \pm 0.03$ \\
\hline \multirow{3}{*}{$3(2.2 \mathrm{SE})$} & $\begin{array}{l}\text { Artemisia } \\
\text { austriaca }\end{array}$ & $11 \pm 1$ & $8 \pm 1$ & $0.21 \pm 0.02$ & $0.15 \pm 0.01$ \\
\hline & Achillea nobilis & $37 \pm 3$ & $24 \pm 2$ & $0.11 \pm 0.01$ & $0.18 \pm 0.02$ \\
\hline & $\begin{array}{c}\text { Ambrosia } \\
\text { artemisiifolia }\end{array}$ & $20 \pm 2$ & $18 \pm 2$ & $0.19 \pm 0.02$ & $0.10 \pm 0.01$ \\
\hline $4 \mathrm{a}(2.1 \mathrm{E})$ & $\begin{array}{l}\text { Triticum } \\
\text { aestivum }\end{array}$ & $7 \pm 1$ & $20 \pm 1$ & $0.16 \pm 0.02$ & $0.09 \pm 0.01$ \\
\hline \multirow{3}{*}{$4(2.1 \mathrm{E})$} & $\begin{array}{l}\text { Artemisia } \\
\text { austriaca }\end{array}$ & $90 \pm 11$ & $7 \pm 1$ & $0.34 \pm 0.04$ & $0.15 \pm 0.02$ \\
\hline & Achillea nobilis & $93 \pm 10$ & $34 \pm 3$ & $0.12 \pm 0.01$ & $0.16 \pm 0.02$ \\
\hline & $\begin{array}{c}\text { Ambrosia } \\
\text { artemisiifolia }\end{array}$ & $72 \pm 6$ & $18 \pm 1$ & $0.17 \pm 0.02$ & $0.05 \pm 0.01$ \\
\hline & L [13] & 50 & - & 0.30 & \\
\hline
\end{tabular}

The data obtained on the Cd content on monitoring sites No. 1, No. 1a, No. 2, and No. 2a were similar to the results obtained by [18], where high concentrations of $\mathrm{Cd}-$ up to 1.7 $\mathrm{mg} / \mathrm{kg}$ - were noted in $H$. perforatum samples. 
A comparative analysis of the studied species of herbaceous plants showed that for Triticum aestivum and Achillea nobilis there was HM accumulation at the root system. In wild plants, $\mathrm{Zn}$ accumulated mainly in the aboveground part. Ambrosia artemisiifolia characterized by the highest $\mathrm{Zn}$ content in the aboveground part, in comparison with other studied plants. Achillea nobilis accumulated more Cd among other wild plants. Due to the selectivity of the element accumulation, different types of plants accumulated various amounts of HM in their organs [6]. It is indicated that a similar high variability of the elemental chemical composition of plants even on the same sites can be associated with different ages of phytomass, rooting depth, mobilization/immobilization of metal by roots in the soil, foliar absorption, etc [5]. Due to the different physiological significance of trace elements, the selectivity of their absorption from soils, their content in plants and various organs varies significantly [19].

\section{Conclusion}

It is established that monitoring sites No. 1 and No. 2, as well as adjacent to them (No. 1a and No. 2a) were the most contaminated. This is originally connected with two factors as follows: firstly, the closer location of these sites to the source of anthropogenic load and secondly, the location of the northwest winds prevailing in the region. It was observed $\mathrm{Zn}$ content in plants was higher than that of $\mathrm{Cd}$ content. Higher content of $\mathrm{Zn}$ in the aboveground part was established for the considered wild-growing herbaceous plants in comparison with the studied agricultural crop. Higher content of $\mathrm{Cd}$ was found in the aboveground part and roots of Triticum aestivum plants. Triticum aestivum accumulates the studied elements mainly in the root system, while wild herbs were characterized by their accumulation in the aboveground part. These differences are associated with the physiological features of the studied plant species and their differentiation in terms of families belonging.

The research was financially supported by the project of the Ministry of Science and Higher Education of the Russian Federation (State assignment in the field of scientific activity, Southern Federal University, 2020) and the grant from the President of Russian Federation, no. MK2818.2019.5.

\section{References}

1. M. Roy, L.M. McDonald, Land Degradation \& Development 26(8), 785-792 (2015)

2. S.A. Anjum, M. Tanveer, S. Hussain, M. Bao, L.C. Wang, I. Khan, E. Ullah, S.A. Tung, R.A. Samad, B. Shahzad, Environmental science and pollution research 22(21), 17022-17030 (2015)

3. A.P.G.C. Marques, A.O.S.S. Rangel, P.M.L. Castro, Critical reviews in environmental science and technology 39, 622-654 (2009)

4. P.J. White, P.H. Brown, Annals of Botany 105, 1073-1080 (2010)

5. A. Kabata-Pendias Trace elements in soils and plants (NW: CRC Press, Taylor and Francis Group, 2011)

6. T.M. Minkina, S.S. Mandzhieva, V.A. Chaplygin, O.G. Nazarenko, A.Y. Maksimov, I.V. Zamulina, M.V. Burachevskaya, S.N. Sushkova, Arid Ecosystems 8(3), 190-202 (2018) 
7. V.A. Chaplygin, S.S. Mandzhieva, T.M. Minkina, S.N. Sushkova, R. Kizilkaya, C. Gulser, I.V. Zamulina, N.E. Kravtsova, I.P. Lobzenko, N.P. Chernikova. Environmental Geochemistry and Health (2019). DOI: 10.1007/s10653-019-00411-6.

8. E. Andresen, H. Küpper, Cadmium: from toxicity to essentiality (Springer, Dordrecht, 2013)

9. Z.J. Zhao, Z.R. Nan, Z.W. Wang, Y.M. Yang, M. Shimizu, Journal of Arid Land 6(1), 59-68 (2014)

10. I. Shtangeeva, A. Viksna, V. Grebnevs, Environmental geochemistry and health 42(1), 209-219 (2020)

11. I. Yermakov, N. Maksimov, A. Evmenyeva, M. Breygina, Plant Reproduction, 31(4), 357-365 (2018).

12. V.B. Ilyin, A.I. Syso, Heavy metals and nonmetals in the soil-plant system (Siberian branch RAS publishing House, Novosibirsk, 2012) (in Russian).

13. T.M. Minkina, S.S. Mandzhieva, G.V. Motuzova, V.A. Chapligin, S.N. Suchkova, Yu.A. Fedorov, S.I. Kolesnikov, T.V. Bauer, Environmental Engineering and Management Journal, 13(5), 1307-1315 (2014)

14. Methodological guidelines on the determination of heavy metals in agricultural soils and crops (Moscow, TsINAO, 1992) (in Russian).

15. G. Du Laing, F.M.G. Tack, M.G. Verloo, Analytica Chimica Acta, 497, 191-198 (2003)

16. Provisional maximum permissible levels (MPL) for some chemical elements and gossypol in forage for farm animals and feed additives (Moscow, 1987) (in Russian)

17. V.B. Ilyin, G.A. Garmash, N.Yu. Garmash, Agrochemistry, 6, 90-100 (1985) (in Russian)

18. D.N. Badea, Revista de Chimie (Bucharest), 66(8), 1132-1136 (2015).

19. V.K. Kashin, L.L. Ubugunov, Agrochemistry 4, 68-76 (2012). 